\title{
Partisipasi Penyusunan Anggaran, Kompetensi, Self-Efficacy Sistem Pengukuran Kinerja dan Kinerja Manajerial
}

\author{
Ni Kadek Dwi Gitariani ${ }^{1}$ \\ Fakultas Ekonomi dan Bisnis \\ Universitas Udayana, Indonesia
}

\author{
Ni Putu Sri Harta Mimba² \\ Fakultas Ekonomi dan Bisnis \\ Universitas Udayana, Indonesia
}

Surel : dwigitariani123@gmail.com

\section{ABSTRAK}

Tujuan penelitian ini adalah untuk menguji pengaruh partisipasi penyusunan anggaran, kompetensi, self-efficacy dan sistem pengukuran kinerja terhadap kinerja manajerial. Penelitian ini dilakukan di Organisasi Perangkat Daerah (OPD) Kabupaten Tabanan. Penelitian ini dilakukan di Organisasi Perangkat Daerah (OPD) Kabupaten Tabanan. Sebanyak 102 orang dipilih menjadi responden. Metode penentuan sampel yang digunakan pada penelitian ini adalah purposive sampling dan teknik analisis data penelitian ini menggunakan analisis regresi linier berganda. Hasil penelitian ini menunjukkan bahwa partisipasi penyusunan anggaran, kompetensi, self efficacy dan sistem pengukuran kinerja berpengaruh positif terhadap kinerja manajerial.

Kata Kunci: Partisipasi Penyusunan Anggaran; Kompetensi; Self-Efficacy; Sistem Pengukuran Kinerja; Kinerja Manajerial.

\section{Participation in Budgeting, Competence, Self-Efficacy of Performance Measurement Systems and Managerial Performance}

\begin{abstract}
The purpose of this study was to examine the effect of budgeting participation, competence, self-efficacy and performance measurement systems on managerial performance. This research was conducted at the Regional Apparatus Organization (OPD) of Tabanan Regency. This research was conducted at the Regional Apparatus Organization (OPD) of Tabanan Regency. A total of 102 people were selected as respondents. The sampling method used in this study was purposive sampling and the data analysis technique used in this study was multiple linear regression analysis. The results of this study indicate that budgetary participation, competence, self-efficacy and performance measurement systems have a positive effect on managerial performance.

Keywords: Participation in Budget Formulation; Competence, Self-Efficacy; Performance Measurement System; Managerial Performance.
\end{abstract}

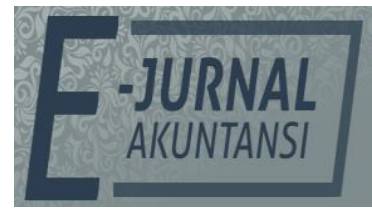

e-ISSN 2302-8556

Vol. 31 No. 3

Denpasar, Maret 2021

Hal. 602-614

DOI:

10.24843/EJA.2021.v31.i03.p07

PENGUTIPAN:

Gitariani, N.K.D., \& Mimba,

N.P.S.H. (2021). Partisipasi

Penyusunan Anggaran,

Kompetensi, Self-Efficacy Sistem Pengukuran Kinerja dan Kinerja Manajerial. EJurnal Akuntansi, 31(3), 602

614

RIWAYAT ARTIKEL:

Artikel Masuk:

14 September 2020

Artikel Diterima:

9 Februari 2021

Artikel dapat diakses : https://ojs.unud.ac.id/index.php/Akuntansi/index 


\section{PENDAHULUAN}

Permendagri Nomor 38 Tahun 2018 tentang Pedoman Penyusunan Anggaran dan Belanja Daerah merupakan pokok kebijakan sebagai petunjuk dan arah bagi Pemerintah Daerah dalam penyusunan, pembahasan dan penetapan APBD. Penyusunan APBD juga harus didasarkan atas pendekatan kinerja, yaitu suatu sistem anggaran yang lebih fokus pada keluaran (output) dan hasil (outcome) dari kegiatan. Penyusunan anggaran dilakukan melalui beberapa tahapan mulai dari tahap evaluasi kinerja yang telah dicapai pada periode sebelumnya, setelah melakukan evaluasi dilakukan penetapan program kerja yang akan dilaksanakan. Setelah kegiatan ditetapkan maka akan dilanjutkan dengan melakukan Musyawarah Rencana Pembangunan (Musrenbang). Kegiatan berikutnya yaitu akan dilakukan penyusunan anggaran masing - masing OPD berupa Rencana Kerja Anggaran (RKA). Selanjutnya masing - masing RKA-OPD yang telah dibuat akan dibahas, disepakati Bersama Kepala OPD dan Tim Anggaran Pemerintahan Daerah (TAPD). Kemudian akan dibahas oleh legislatif bersama dengan pemerintah daerah. Pemerintah sering memiliki permasalahan dalam penyusunan anggaran yaitu realisasi yang lebih rendah dari pada anggaran biaya yang ditetapkan.

Tabel 1. Realisasi Anggaran Pendapatan dan Belanja Daerah (APBD) Kabupaten/Kota di Bali Tahun 2014 - 2018

\begin{tabular}{ccccc}
\hline Tahun & $\begin{array}{c}\text { Anggaran } \\
\text { Pendapatan } \\
\text { Daerah }\end{array}$ & $\begin{array}{c}\text { Realisasi } \\
\text { Pendapatan } \\
\text { Daerah }\end{array}$ & $\begin{array}{c}\text { Anggaran } \\
\text { Belanja Daerah }\end{array}$ & $\begin{array}{c}\text { Realisasi } \\
\text { Belanja } \\
\text { Daerah }\end{array}$ \\
\hline 2014 & 1.328 .610 .781 & 1.367 .063 .683 & 1.415 .634 .479 & 1.333 .200 .899 \\
2015 & 1.598 .653 .208 & 1.615 .933 .308 & 1.714 .702 .582 & 1.586 .227 .841 \\
2016 & 1.914 .766 .565 & 1.794 .601 .450 & 2.060 .891 .636 & 1.873 .464 .986 \\
2017 & 1.913 .540 .384 & 1.871 .864 .102 & 2.184 .423 .902 & 1.861 .962 .379 \\
2018 & 1.948 .668 .063 & 1.862 .277 .203 & 2.214 .812 .691 & 1.909 .975 .375 \\
\hline
\end{tabular}

Sumber: Data Penelitian, 2020

Berdasarkan Tabel 1, APBD Pemerintahan Kabupaten Tabanan dapat dilihat bahwa pada tahun 2014 - 2015 terjadi peningkatan pada realisasi anggaran pendapatan daerah, namun pada tahun 2016 - 2018 terjadi penurunan pada realisasi anggaran pendapatan daerah. Sedangkan realisasi belanja juga menunjukkan realisasi yang lebih rendah dan tidak mencapai $100 \%$, hal tersebut menunjukkan bahwa anggaran belanja tidak digunakan secara optimal. Rendahnya realisasi anggaran tersebut dapat menunjukkan masih belum maksimalnya seseorang yang bekerja pada instansi pemerintahan untuk membuat perencanaan dengan baik, hal tersebut dapat dikatakan bahwa kinerja manajerial OPD Kabupaten Tabanan masih kurang efektif dalam merealisasi anggaran yang telah direncanakan dan dari segi output dan outcome masih belum maksimal. Hal tersebut juga membuat peneliti untuk memeriksa perilaku anggaran dalam sektor publik dengan beberapa faktor yang diduga dapat mempengaruhi kinerja manajerial selain partisipasi penyusunan anggaran yakni, kompetensi, self efficacy dan sistem pengukuran kinerja.

Partisipasi penyusunan anggaran merupakan kegiatan yang melibatkan berbagai pihak, baik manajer tingkat atas maupun manajer tingkat bawah dimana masing - masing pihak memainkan peran dalam mempersiapkan dan 
mengevaluasi berbagai alternatif dan tujuan anggaran (Setyowati \& Purwantoro, 2013). Partisipasi penyusunan anggaran ini diperlukan karena bawahan yang lebih mengetahui kondisi langsung bagiannya (Sujana, 2010). Adanya partisipasi penyusunan anggaran dapat menjadi sarana pertukaran informasi antara atasan dan bawahan. Dimana informasi yang dibagikan oleh bawahan dapat dijadikan sebagai bahan pertimbangan dalam menetapkan sasaran di dalam anggaran maupun pengambilan keputusan pada aktivitas lainnya sehingga dapat meningkatkan kinerja manajerial.

Dalam penyusunan anggaran terdapat dua macam metode partispasi yang dapat dilakukan, yaitu dengan metode top-down dan bottom-up (Rosalina, 2011) Metode top-down merupakan metode penyusunan anggaran, yang mana manajemen level atas melakukan penyusunan anggarannya, sedangkan manajemen level menengah dan bawah hanya melaksanakan anggarannya saja. Sedangkan metode bottom-up merupakan metode penyusunan anggaran yang dilakukan oleh manajemen level bawah kemudian dilanjutkan oleh manajemen level menengah dan disahkan oleh manajemen level atas (Sucitrawati \& Sari, 2017). Partisipasi anggaran merupakan pendekatan yang secara umum dapat meningkatkan prestasi atau kinerja yang pada akhirnya dapat meningkatkan efektivitas suatu organisasi.

Beberapa penelitian mengenai pengaruh partisipasi penyusunan anggaran terhadap kinerja manajerial telah banyak dilakukan oleh penelitian - penelitian terdahulu dan menunjukkan hasil yang tidak menyakinkan dan seringkali bertentangan. Rizandi et al (2015) dan Karakoc \& Ozer (2016) mengemukakan bahwa partisipasi penyusunan anggaran berpengaruh positif terhadap kinerja manajerial, yang berarti semakin tinggi tingkat partisipasi dalam penyusunan anggaran akan mengakibatkan meningkatnya kinerja manajerial. Berbeda dengan penelitian yang dilakukan Idrianto (2018), Ermawati (2017) dan Syahputra (2014) menunjukkan hasil yang berbeda yaitu partisipasi penyusunan anggaran tidak memiliki pengaruh terhadap kinerja manajerial.

Kompetensi merupakan kemampuan untuk melaksanakan tugas yang didasari atas pengetahuan, keterampilan dan sikap. Menurut Trotter (1986) dalam Wasana \& Wirajaya (2015) mendefinisikan bahwa seorang yang kompeten adalah orang yang dengan keterampilannya mengerjakan pekerjaan yang mudah, cepat, intuitif dan sangat jarang atau tidak pernah membuat kesalahan. Hal ini menunjukkan bahwa manajerial harus mampu memiliki kemampuan yang baik dalam menjalankan tugasnya agar hasil dari kinerja manajerial relevan dan handal. Hasil penelitian Sulistyaningsih (2009) menyatakan bahwa kompetensi berpengaruh positif dan signifikan terhadap kinerja manajerial.

Faktor lain yang mempengaruhi kinerja manajerial, yaitu self efficacy. Self efficacy merupakan persepsi/keyakinan tentang kemampuan diri sendiri. Self efficacy atau keyakinan diri memiliki peranan penting dalam menentukan kinerja manajerial. Bandura (1993) menyatakan bahwa self efficacy adalah kepercayaan seseorang bahwa dia dapat menjalankan sebuah tugas pada sebuah tingkat tertentu, yang mempengaruhi aktifitas pribadi terhadap pencapaian tujuan. Berdasarkan penelitian yang dilakukan Judge \& Bono (2001), self efficacy akan mendorong seseorang lebih bersemangat mencapai hasil optimal dalam kinerjanya. Individu dengan self efficacy yang tinggi cenderung bersemangat 
dalam usahanya mencapai tujuan, meskipun berhadapan dengan berbagai masalah dan pengalaman kegagalan, sedangkan individu dengan self efficacy yang rendah cenderung berdiam diri dan menyerah apabila berhadapan dengan masalah atau hambatan yang ada. Hasil penelitian Yuniarti (2019) dan Cavazotte et al (2013) menyimpulkan bahwa self efficacy berpengaruh positif dan signifikan terhadap kinerja manajerial.

Sistem pengukuran kinerja diharapkan dapat memberikan informasi yang sesuai dalam pengambilan keputusan bagi manajer dan meningkatkan kinerja organisasi. Menurut Mulyadi (2007) pengukuran kinerja adalah penentuan secara periodik efektifitas operasional suatu organisasi dan personelnya, berdasarkan sasaran dan kriteria yang ditetapkan serta untuk menilai hasil akhir apakah program atau kegiatan yang telah direncanakan dan dilaksanakan sesuai dengan rencana tersebut. Pengukuran kinerja sangat penting untuk menilai akuntabilitas organisasi dan manajer dalam menghasilkan pelayanan publik yang lebih baik (Mardiasmo, 2002).

Sistem pengukuran kinerja yang dilakukan dengan cara yang adil, berbobot, dan dilakukan dengan secara berkala akan sangat membantu mengevaluasi dan meningkatkan kinerja manajerial (Sianipar, 2013). Dengan adanya sistem pengukuran kinerja keberhasilan suatu instansi pemerintahan akan dilihat dari kemampuan instansi tersebut berdasarkan sumber daya yang dikelolanya untuk mencapai hasil sesuai dengan rencana yang telah tertuang dalam perencanaan strategis. Menurut Mulyadi (2007) sistem pengukuran kinerja diharapkan dapat membantu manajer memperbaiki kinerja dalam mewujudkan tujuan dan sasaran, efisiensi dan efektivitas layanan publik secara transparan, membantu alokasi sumber daya dan pembuatan keputusan.

Dengan adanya upaya keterlibatan langsung dalam penyusunan anggaran, maka akan menciptakan komunikasi yang baik antar anggota tim, sehingga tercipta motivasi yang besar untuk mencapai tujuan organisasi. Penetapan anggaran juga dapat tercipta dengan baik karena adanya campur tangan dan usulan dari setiap unit-unit kerja untuk memutuskan anggaran yang sesuai dengan kondisi dan kebutuhan. Jadi, semakin tinggi partisipasi anggaran dalam organisasi, maka akan meningkatkan kinerja pemerintah daerah. Dalam pembuatan anggaran dibutuhkan keyakinan dari partisipasi dari manajemen tingkat atas maupun tingkat bawah, yang akan bertugas untuk mempersiapkan dan mengevaluasi anggaran tersebut, dimana nantinya anggaran akan digunakan sebagai tolak ukur bagi kinerja manajer (Wijaya \& Lucyanda, 2016).

Penelitian Wiratno et al. (2016) menunjukkan hasil bahwa partisipasi penyusunan anggaran memiliki pengaruh positif yang signifikan terhadap kinerja manajerial, hal ini menunjukkan semakin tinggi partisipasi manajer dalam penyusunan anggaran, maka akan semakin tinggi pula kinerja manajerial perusahaan. Hasil yang sama juga didukung oleh Lina (2015) dan Syafriadi (2015), yang menyatakan bahwa partisipasi partisipasi penyusunan anggaran berpengaruh terhadap kinerja manajerial. Berdasarkan uraian di atas dan penelitian sebelumnya, maka dapat dirumuskan hipotesis sebagai berikut.

$\mathrm{H}_{1}$ : Partisipasi penyusunan anggaran berpengaruh positif terhadap kinerja manajerial. 
Kompetensi adalah suatu kemampuan untuk melaksanakan atau melakukan suatu pekerjaan atau tugas yang dilandasi atas keterampilan dan pengetahuan serta didukung oleh sikap kerja yang dituntut oleh pekerjaan tersebut (Wibowo 2014;271). Dalam meningkatkan kinerja manajerial, kompetensi merupakan sesuatu yang sangat penting dimiliki oleh manajer. Kompetensi mencerminkan kemampuan manajer untuk menjalin kerjasama serta berinteraksi dengan orang lain dalam bekerja untuk mencapai tujuan pribadi maupun tujuan organisasi. Semakin tinggi kompetensi yang dimiliki maka semakin tinggi kinerja manajerial dan sebaliknya jika kompetensi yang dimiliki rendah maka akan menyebabkan rendahnya kinerja manajerial.

Berdasarkan hasil penelitian yang dilakukan Fuad (2016) menyatakan bahwa kompetensi berpengaruh positif namun tidak signifikan terhadap kinerja manajerial. Penelitian tersebut juga didukung oleh Wasana \& Wirajaya (2015) dan Yudistira \& Siwantara (2013) menyatakan bahwa kompetensi berpengaruh positif terhadap kinerja manajerial. Berdasarkan uraian sebelumnya, dapat disusun hipotesis sebagai berikut.

$\mathrm{H}_{2}$ : Kompetensi berpengaruh positif terhadap kinerja manajerial.

Self efficacy merupakan suatu keyakinan yang dimiliki individu tentang kemampuan dirinya terhadap tindakan yang diperlukan untuk mencapai tuntutan dari kinerja (Dewi, 2012). Self efficacy berhubungan dengan keyakinan diri individu memiliki kemampuan pada tugas tertentu, dan dianggap sebagai salah satu faktor utadima mendorong pencapaian tujuan. Oleh karena itu, diasumsikan bahwa self efficacy yang lebih besar dalam kaitannya dengan aktivitas tertentu akan memperbesar keterlibatan dan ketekunan individu dalam mencapai tujuan tersebut (Cavazotte et al ., 2013)

Self efficacy dapat meningkatkan kinerja karena individu yang memiliki self efficacy yang tinggi cenderung akan melalukan tindakan yang berkaitan dengan tugas dan bertahan lama pada tugas tersebut meskipun mengalami kemunduran. Sebaliknya, individu dengan self efficacy yang rendah cenderung untuk menghentikan usaha mereka dan gagal pada tugas (Tims et al., 2014). Berdasarkan goal setting theory yang menjelaskan hubungan antara tujuan yang didasari dengan kinerja, maka dapat diasumsikan bahwa individu yang memiliki self efficacy yang tinggi akan memiliki keyakinan dalam melaksanakan anggaran.

Berdasarkan hasil dari penelitian yang dilakukan oleh Wahab et al. (2015) Cavazotte et al (2013), Wahab et al (2015) dan Negara (2017) yang menyatakan self efficacy berpengaruh positif terhadap kinerja manajerial. Berdasarkan uraian sebelumnya, dapat disusun hipotesis sebagai berikut.

$\mathrm{H}_{3}$ : Self Efficacy berpengaruh positif terhadap kinerja manajerial.

Pengukuran kinerja merupakan suatu proses yang harus dilakukan dalam upaya pengendalian tenaga kerja, penilaian tersebut dimaksudkan untuk memperoleh informasi yang akurat dan valid mengenai perilaku dan kinerja anggota organisasi (Swari \& Wirasedana, 2017). Sistem pengukuran kinerja menyediakan informasi yang relevan dengan pengambilan keputusan. Sistem pengukuran kinerja merupakan suatu hal yang sangat penting dalam organisasi untuk mengetahui apakah selama ini pelaksanaan kinerja terdapat kesenjangan dari rencana yang telah ditentukan atau apakah kinerja dapat dilakukan sesuai 
dengan yang diharapkan. Sistem pengukuran kinerja yang dilakukan oleh organisasi akan memotivasi manajer untuk bekerja lebih baik karena prestasi kerjanya sangat diperlukan untuk mengevaluasi kinerja manajerial dimasa yang akan datang (Purnamaningsih, 2017).

Hasil penelitian Purba (2017) menunjukkan bahwa sistem pengukuran kinerja berpengaruh positif terhadap kinerja manajerial. Selain itu hasil penelitian yang dilakukan oleh Negara (2017), Simorangkir (2013), dan Handayani (2013) yang menyatakan bahwa sistem pengukuran kinerja berpengaruh positif terhadap kinerja manajerial. Namun hasil penelitian dari Jusuf (2013) dan Dasrita et al (2015) menunjukkan hal yang berbeda, yaitu tidak adanya pengaruh antara sistem pengukuran kinerja dengan kinerja manajerial. Berdasarkan uraian sebelumnya, dapat disusun hipotesis sebagai berikut.

$\mathrm{H}_{4}$ : Sistem Pengukuran Kinerja berpengaruh positif terhadap kinerja manajerial.

\section{METODE PENELITIAN}

Lokasi penelitian ini dilakukan pada Organisasi Perangkat Daerah (OPD) Kabupaten Tabanan yang berjumlah 34 unit. Pemilihan OPD Kabupaten Tabanan dikarenakan secara umum proses penyusunan anggaran pada pemerintahan Tabanan memiliki kompleksitas yang sangat rumit, dimana setiap alokasi biaya yang direncanakan harus dikaitkan dengan tingkat pelayanan atau hasil yang diharapkan dapat tercapai.

Populasi yang digunakan pada penelitian ini adalah pejabat struktural pada Organisasi Perangkat Daerah (OPD) Kabupaten Tabanan yang terdiri dari kepala dinas/badan/sekretaris kantor, kabag keuangan, dan kasubag penganggaran \& perencanaan. Pemilihan sampel ini menggunakan metode sampel purposive sampling dengan tujuan mendapatkan sampel yang representatif yang sesuai dengan kriteria yang telah ditentukan. Purposive sampling merupakan teknik penentuan sampel berdasarkan pertimbangan tertentu. Sampel dalam penelitian ini sebanyak 102 orang responden. Sampel dipilih berdasarkan kriteria tertentu yang dapat mendukung penelitian ini. Kriteria pemilihan sampel dalam penelitian ini adalah Pejabat Struktural pada OPD Kabupaten Tabanan yang memiliki peran dalam proses penyusunan anggaran (RKA-OPD) dan Pejabat Struktural yang memiliki masa kerja minimal satu tahun dalam periode penyusunan anggaran.

Metode pengumpulan data yang digunakan dalam penelitian ini adalah metode survei dengan teknik kuesioner. Analisis regresi linier berganda digunakan untuk melihat pengaruh variabel independen terhadap variabel dependen, dimana variabel dependen $(X)$ adalah Partisipasi Penyusunan Anggaran, Kompetensi, Self Efficacy dan Sistem Pengukuran Kinerja sedangkan variabel independen (Y) Kinerja Manajerial. Pengujian ini dilakukan dengan menggunakan bantuan program SPSS. Model regresi berganda dalam penelitian ini adalah sebagai berikut :

$Y=a+\beta_{1} X_{1}+\beta_{2} X_{2}+\beta_{3} X_{3}+\beta_{4} X_{4}+\varepsilon$

Keterangan:

$\mathrm{Y}=$ Kinerja manajerial

a $\quad=$ Konstanta

$\mathrm{X}_{1} \quad=$ Partisipasi penyusunan anggaran 


$$
\begin{array}{ll}
X_{2} & =\text { Kompetensi } \\
X_{3} & =\text { Self Efficacy } \\
X_{4} & =\text { Sistem Pengukuran Kinerja } \\
\beta 1, \beta 2, \beta 3, \beta 4 & =\text { Koefisien regresi } \\
\varepsilon & =\text { Komponen error }
\end{array}
$$

\section{HASIL DAN PEMBAHASAN}

Statistik deskriptif dalam penelitian menyampaikan informasi mengenai karakteristik variabel-variabel penelitian yang terdiri dari jumlah pengamatan, nilai minimum, nilai maksimum, nilai rata dan standar deviasi. Tabel 2, memperlihatkan hasil analisis statistik deskriptif.

Tabel 2. Hasil Uji Statistik Deskriptif

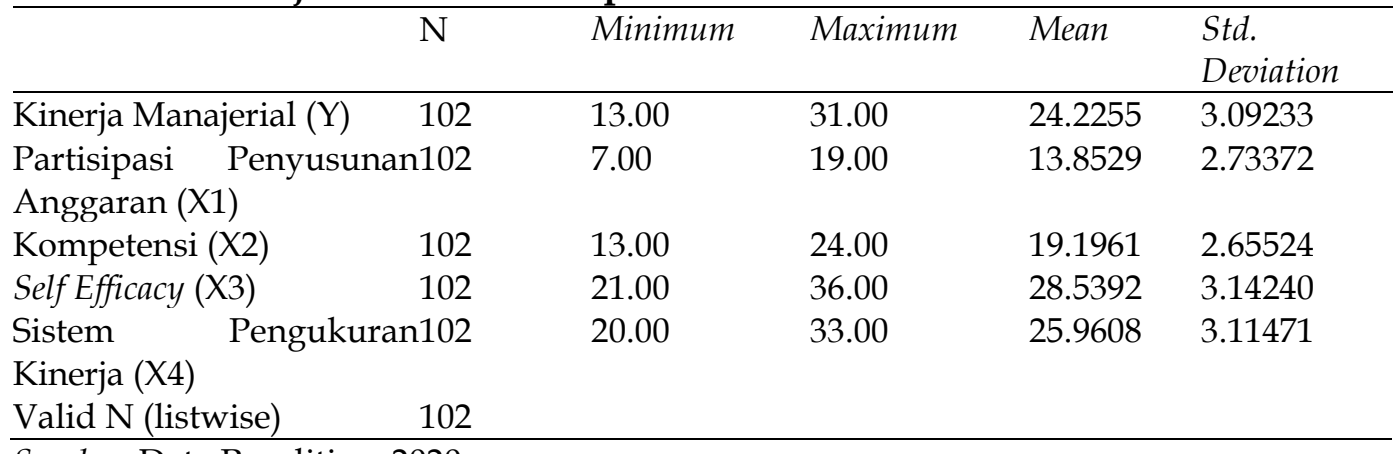

Sumber: Data Penelitian, 2020

Variabel kinerja manajerial $(Y)$ memiliki nilai minimum sebesar 13,00 dan nilai maksimum sebesar 31,00. Nilai rata - rata untuk variabel kinerja manajerial adalah sebesar 24,2255. Standar deviasi sebesar 3,09233. Hal ini menunjukkan bahwa standar penyimpangan data terhadap nilai rata - ratanya adalah 3,09233.

Variabel partisipasi penyusunan anggaran (X1) memiliki nilai minimum sebesar 7,00 dan nilai maksimum sebesar 19,00. Nilai rata - rata untuk variabel partisipasi penyusunan anggaran adalah 13,8529. Standar deviasi sebesar 2,73372. Hal ini menunjukkan bahwa standar penyimpangan data terhadap nilai rata - ratanya adalah 2,73372 .

Variabel kompetensi (X2) memiliki nilai minimum sebesar 13,00 dan nilai maksimum sebesar 24,00. Nilai rata - rata untuk variabel kompetensi adalah 19,1961. Standar deviasi sebesar 2,65524. Hal ini menunjukkan bahwa standar penyimpangan data terhadap nilai rata - ratanya adalah 2,65524.

Variabel self efficacy (X3) memiliki nilai maksimum sebesar 21,00 dan nilai maksimum sebesar 24,000. Nilai rata - rata untuk variabel self efficacy adalah sebesar 28,5392. Standar deviasi sebesar 3,14240. Hal ini menunjukkan bahwa standar penyimpangan data terhadap nilai rata - ratanya sebesar 3,14240.

Variabel sistem pengukuran kinerja (X4) memiliki nilai minimum sebesar 20,00 dan nilai maksimum sebesar 33,000. Nilai rata - rata untuk variabel sistem pengukuran kinerja adalah sebesar 25,9608. Standar deviasi sebesar 3,11471. Hal ini menunjukkan bahwa standar penyimpangan data terhadap nilai rata ratanya sebesar 3,11471.

Perhitungan koefisien regresi linier berganda dilakukan dengan analisis regresi melalui software SPSS 18.0 for Windows, diperoleh hasil yang ditunjukan pada Tabel 3. 
Tabel 3. Hasil Analisis Regresi Linier Berganda

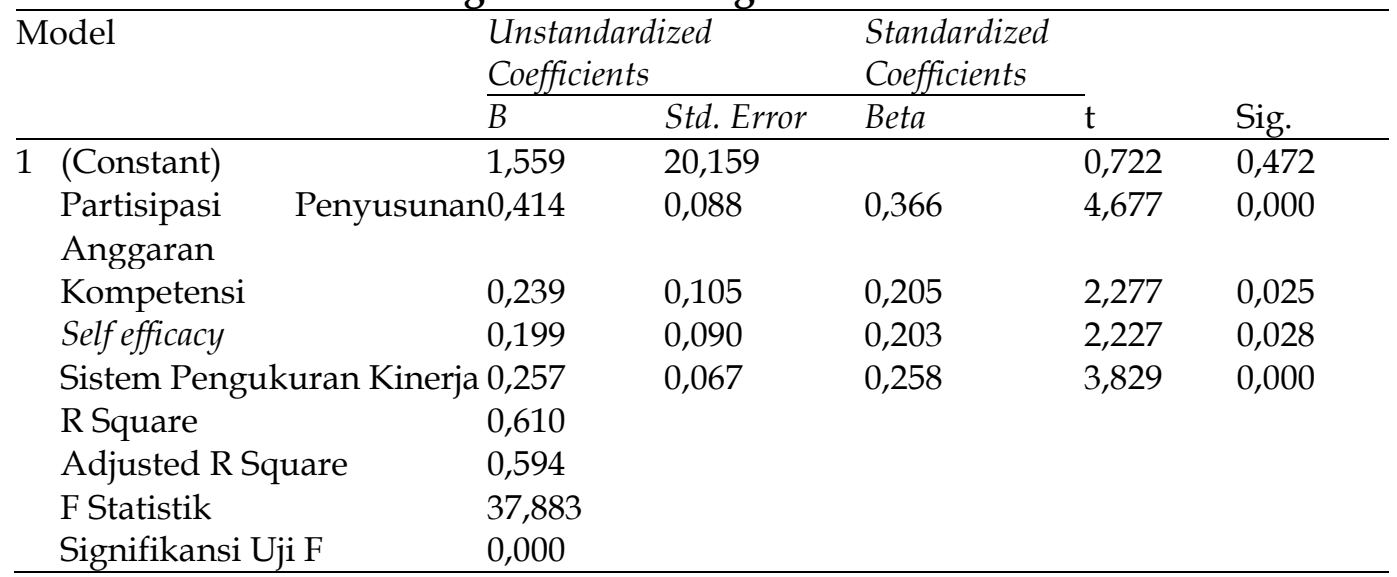

Sumber: Data Penelitian, 2020

Berdasarkan hasil analisis regresi linier berganda seperti yang disajikan pada Tabel 3, maka dapat dibuat persamaan regresi sebagai berikut.

$$
\mathrm{Y}=1,559+0,414 \mathrm{X}_{1}+0,239 \mathrm{X}_{2}+0,199 \mathrm{X}_{3}+0,257 \mathrm{X}_{4}
$$

Hipotesis pertama dalam penelitian ini menyatakan bahwa partisipasi penyusunan anggaran berpengaruh positif terhadap kinerja manajerial di OPD Kabupaten Tabanan. Hasil pengujian dengan menggunakan regresi linier berganda sejalan dengan hipotesis yang telah dirumuskan. Nilai regresi menunjukkan nilai signifikan sebesar $0,000<0,05$. Dari hasil nilai regresi tersebut menunjukkan bahwa partisipasi penyusunan anggaran berpengaruh positif terhadap kinerja manajerial. Hasil ini memiliki arti bahwa semakin tinggi tingkat partisipasi penyusunan anggaran, maka semakin tinggi kinerja manajerial di OPD Kabupaten Tabanan. Partisipasi penyusunan anggaran merupakan keterlibatan para manajer dalam proses penyusunan anggaran untuk mencapai tujuan bersama di masa yang akan datang. Dengan adanya partisipasi tersebut para manajer akan terdorong untuk lebih bertanggungjawab terhadap masing-masing tugas yang diembannya, sehingga para manajer akan meningkatkan kinerjanya agar mereka dapat mencapai sasaran atau target yang telah ditetapkan secara bersama dalam anggaran. Hasil penelitian ini sesuai dengan Wiratno et al. (2016) yang menunjukkan hasil bahwa partisipasi penyusunan anggaran berpengaruh positif terhadap kinerja manajerial.

Hipotesis kedua penelitian ini menyatakan bahwa kompetensi berpengaruh positif terhadap kinerja manajerial di OPD Kabupaten Tabanan. Hasil pengujian dengan menggunakan regresi linier berganda sejalan dengan hipotesis yang telah dirumuskan. Nilai regresi menunjukkan nilai signifikan sebesar $0,000<0,05$. Dari hasil nilai regresi tersebut menunjukkan bahwa kompetensi berpengaruh positif terhadap kinerja manajerial. Hasil ini memiliki arti bahwa semakin tinggi kompetensi yang dimiliki maka semakin tinggi kinerja manajerial.

Kompetensi adalah suatu kemampuan untuk melaksanakan suatu pekerjaan yang dilandasi atas keterampilan, pengetahuan serta didukung oleh sikap kerja yang dituntut oleh pekerjaan tersebut. Untuk meningkatkan kinerja manajerial, kompetensi merupakan sesuatu yang sangat penting dimiliki oleh manajer. Kompetensi mencerminkan kemampuan. Manajer untuk menjalin 
kerjasama serta berinteraksi dengan orang lain dalam bekerja untuk mencapai tujuan pribadi maupun tujuan organisasi. Hasil penelitian ini mendukung penelitan yang dilakukan oleh Wasana \& Wirajaya (2015) dan Yudistira \& Siwantara (2013) dalam penelitiannya kompetensi berpengaruh positif terhadap kinerja manajerial.

Hipotesis ketiga penelitian ini menyatakan bahwa self efficacy berpengaruh positif terhadap kinerja manajerial di OPD Kabupaten Tabanan. Hasil pengujian dengan menggunakan regresi linier berganda sejalan dengan hipotesis yang telah dirumuskan. Nilai regresi menunjukkan nilai signifikan sebesar $0,000<0,05$. Dari hasil nilai regresi tersebut menunjukkan bahwa self efficacy berpengaruh positif terhadap kinerja manajerial.

Self efficacy merupakan suatu keyakinan yang dimiliki individu tentang kemampuan dirinya terhadap tindakan yang diperlukan untuk mencapai tuntutan dari kinerja. Berdasarkan goal setting theory yang menjelaskan hubungan antara tujuan yang didasari dengan kinerja, maka dapat disimpulkan bahwa individu yang memiliki self efficacy yang tinggi akan mampu melaksanakan anggaran dengan baik dan juga dapat meningkatkan kinerja manajerial. Hasil penelitian ini mendukung penelitian yang dilakukan oleh Wahab et al. (2015), Cavazotte et al. (2013) dan Negara (2017) yang menyatakan self efficacy berpengaruh positif terhadap kinerja manajerial.

Hipotesis keempat penelitian ini menyatakan bahwa sistem pengukuran kinerja berpengaruh positif terhadap kinerja manajerial di OPD Kabupaten Tabanan. Hasil pengujian dengan menggunakan regresi linier berganda sejalan dengan hipotesis yang telah dirumuskan. Nilai regresi menunjukkan nilai signifikan sebesar $0,000<0,05$. Dari hasil nilai regresi tersebut menunjukkan bahwa sistem pengukuran kinerja berpengaruh positif terhadap kinerja manajerial. Hasil ini memiliki arti bahwa jika sistem pengukuran kinerja yang diterapkan semakin ditingkatkan, maka kinerja manajerial di OPD Kabupaten Tabanan juga akan meningkat.

Sistem pengukuran kinerja yang dilakukan oleh organisasi akan memotivasi manajer untuk bekerja lebih baik karena prestasi kerjanya sangat diperlukan untuk mengevaluasi kinerja manajerial dimasa yang akan datang. Hasil penelitian ini mendukung penelitian yang dilakukan oleh Purba (2017) dan Negara (2017) yang menyatakan bahwa sistem pengukuran kinerja berpengaruh positif terhadap kinerja manajerial.

Koefisien determinasi $\left(\mathrm{R}^{2}\right)$ digunakan untuk mengetahui dan mengukur kemampuan model dalam menerangkan variasi variabel independen. Peneliti menggunakan nilai adjusted $\mathrm{R}^{2}$ pada saat mengevaluasi yang mana model regresi terbaik, karena tidak seperti $\mathrm{R}^{2}$, nilai adjusted $\mathrm{R}^{2}$ dapat naik atau turun apabila satu variabel independen ditambahkan ke dalam model.

Tabel 4. Hasil Uji Koefisien Determinasi $\left(\mathbf{R}^{2}\right)$

\begin{tabular}{lllllr}
\hline Model & $R$ & $R$ Square & Adjusted $R$ Square & $\begin{array}{l}\text { Std. Error of the } \\
\text { Estimate }\end{array}$ & \\
\hline 1 & $0,781^{\text {a }}$ & 0,610 & 0,594 & 1,97131 & \\
\hline
\end{tabular}

Sumber: Data Penelitian, 2020

Berdasarkan hasil uji pada Tabel 5 memberikan hasil dimana besarnya pengaruh variabel bebas terhadap variabel terikat yang ditunjukkan oleh nilai 
determinasi total ( $\mathrm{R}$ Square) sebesar 0,610, hal ini berarti bahwa 61\% variasi Kinerja manajerial dipengaruhi oleh variasi partisipasi penyusunan anggaran, kompetensi, self efficacy, dan sistem pengukuran kinerja, sedangkan sisanya sebesar 39\% dijelaskan oleh faktor lain yang tidak dimasukkan ke dalam model.

Uji ketepatan model regresi bertujuan untuk mengetahui apakah semua variabel bebas yang diidentifikasi (Partisipasi Penyusunan Anggaran, Kompetensi, self efficacy, dan Sistem Pengukuran Kinerja) tepat digunakan memprediksi kinerja manajerial. Uji ini sering juga disebut dengan uji $\mathrm{F}$ dengan hasil sebagai berikut:

Tabel 5. Hasil Uji F

\begin{tabular}{lllllll}
\hline Model & & Sum of Squares & $d f$ & Mean Square & F & Sig. \\
\hline 1 & Regression & 588.865 & 4 & 147.216 & 37.883 & $.000^{\mathrm{a}}$ \\
& Residual & 376.949 & 97 & 3.886 & & \\
& Total & 965.814 & 101 & & & \\
\hline
\end{tabular}

Sumber: Data Penelitian, 2020

Berdasarkan hasil uji pada Tabel 6, variabel independen berpengaruh serempak (simultan) terhadap variabel dependen Signifikan F sebesar 0,000 < 0,05. Hasil uji $\mathrm{F}$ yang di analisis dengan menggunakan program SPSS diperoleh nilai $\mathrm{F}_{\text {hitung }}$ sebesar 37,883, dengan nilai sig. 0,000<0,05, maka dapat disimpulkan bahwa pada kelompok yang diuji memiliki perbedaan yang nyata (signifikan). Hasil ini mempunyai arti bahwa ada pengaruh signifikan antara faktor partisipasi penyusunan anggaran, kompetensi, self efficacy dan sistem pengukuran kinerja terhadap kinerja manajerial.

\section{SIMPULAN}

Penelitian yang dilakukan diharapkan dapat memberikan hasil mengenai pengaruh partisipasi anggaran, kompetensi, self efficacy dan sistem pengukuran kinerja terhadap kinerja manajerial pada OPD Kabupaten Tabanan. Hasil uji hipotesis dalam penelitian ini menemukan bahwa variabel independen yaitu partisipasi penyusunan anggaran, kompetensi, self efficacy dan sistem pengukuran kinerja berpengaruh positif terhadap kinerja manajerial. Penelitian ini mendukung goal setting theory yaitu keterlibatan menetapkan anggaran secara langsung akan menciptakan komunikasi yang baik antar anggota, karena komunikasi yang baik akan meminimalisir kegagalan pencapaian tujuan dan akan menciptakan tujuan yang dapat dicapai secara baik dan penilaian kinerja baik.

Penelitian ini dapat memberikan implikasi bagi OPD Kabupaten Tabanan untuk meningkatkan kinerja manajerial dan sebagai pengetahuan mengenai kinerja manjerial serta faktor-faktor yang dapat mempengaruhi kinerja manajerial Instansi. Bagi peneliti selanjutnya, penelitian ini diharapkan dapat menjadi bahan rujukan untuk menambah informasi yang diperlukan.

\section{REFERENSI}

Bandura, A. (1977). Self-efficacy: Toward a Unifying Theory of Behavioral Change. Psychological Review, 84(2), 191-215. https:// doi.org/10.1007/978-3319-75361-4

Bandura, A. (1993). Perceived Self-efficacy in Cognitive Development and 
Functioning. In Educational psychologist (Vol. 28, Issue 2, pp. 117-148). https://www.tandfonline.com/doi/abs/10.1207/s15326985ep2802_3

Cavazotte, F., Moreno, V., \& Jane, B. (2013). Transformational Leaders and Work Performance: The Mediating Roles of Identification and Self-efficacy. BARBrazilian Administration Review, 10(4), 490512.

Dasrita, T., Rusli Tanjung, A., \& Mutia Basri, Y. (2015). Hubungan Sistem Pengukuran Kinerja dengan Kinerja Manajerial: Peran Keadilan Prosedural, Kejelasan Peran, dan Komitmen Organisasi sebagai Variabel Pemediasi. Jurnal Sorot, 10(2), 195-210. https:/ / doi.org/10.31258/sorot.10.2.3215

Dewi, R. (2012). Kinerja Kepala Sekolah: Pengaruh Kepemimpinan Transformasional, Konflik Dan Efikasi Diri. Jurnal Ilmu Pendidikan, 18(2), 150-156

Ermawati, N. (2017). Pengaruh Partisipasi Anggaran Terhadap Kinerja Manajerial Dengan Motivasi Kerja Sebagai Variabel Pemoderasi (Studi Kasus Skpd Kabupaten Pati). Jurnal Akuntansi Indonesia, 6(2), 141-156. https://doi.org/10.30659/jai.6.2.141-156

Fabian, D. (2017). Pengaruh Self Efficacy dan Motivasi Terhadap Kepuasan Kerja Karyawan Pada PT. PP London Sumatera Indonesia TBK. Skripsi Universitas Sumatra Utara.

Fuad, E. N. (2016). Pengaruh Kompetensi dan Motivasi Kerja Terhadap Kinerja Manajer Koperasi Di Kabupaten Jepara. University Research Colloquim, 217226.

Handayani, D. F. (2013). Pengaruh Sistem Pengukuran Kinerja dan Kompensasi Terhadap Kinerja Manajerial (Studi Empiris pada Perusahaan Manufaktur di Kota Padang). Jurnal Ekonomi Akuntansi, September, 1-25.

Idrianto, O. (2018). Pengaruh Partisipasi Anggaran Terhadap Kinerja Manajerial Dengan Job Relevant Information Dan Gaya Kepemimpinan Sebagai Variabel Moderasi (Studi Empiris Seluruh Manajer Rumah Sakit Umum Pemerintah di Provinsi Riau). JOM Fekon, 5(1), 550-556.

Judge, T. A., \& Bono, J. E. (2001). Relationship of Core Self-Evaluations Traits Self-Esteem, Generalized Self-Efficacy, Locus of Control, and Emotional Stability - With Job Satisfaction and Job Performance: A meta-analysis. Journal of Applied Psychology, 86(1), 80-92. https://doi.org/10.1037/00219010.86.1.80

Jusuf, R. S. (2013). Analisis Pengaruh Tqm, Sistem Pengukuran Kinerja Dan Reward Terhadap Kinerja Manajerial. Jurnal Riset Ekonomi, Manajemen, Bisnis Dan Akuntansi, 1(3), 634-644.

Mardiasmo. (2002). Akuntansi Sektor Publik. Yogyakarta : Andi.

Mardiasmo. (2009). Akuntansi Sektor Publik. Yogyakarta: Andi.

Mulyadi. (2007). Sistem Perencanaan dan Pengendalian Manajemen. Jakarta: Salemba Empat.

Mukaromah, U. (2018). Pengaruh Partisipasi Anggaran, Desentralisasi, Akuntabilitas Publik Terhadap Kinerja Manajerial SKPD Dengan Pengawasan Internal Sebagai Variabel Moderasi (Studi Pada Satuan Kerja Perangkat Daerah Karangayar). Skripsi Fakultas Ekonomi Dan Bisnis. Institut Agama Islam Negeri Surakarta, 1-137.

Nadler, D., \& Tushman, M. (1988). Strategic Organisation Design. Harper Collins. 
Negara, I. G. J., \& Gayatri. (2017). Pengaruh Partisipasi Anggaran, Self Efficacy, Sistem Pengukuran Kinerja, Dan Sistem Reward Pada Kinerja Manajerial. EJurnal Akuntansi Universitas Udayana, 20(3), 2479-2508.

Putri, I. A. D., \& Mimba, N. P. S. H. (2017). Pengaruh Partisipasi Anggaran, Asimetri Informasi dan Preferensi Risiko pada Senjangan Anggaran. EJurnal Akuntansi Universitas Udayana, 21(3), 2134-2164. https://doi.org/https://doi.org/10.24843/EJA.2017.v21.i03.p16

Purnamaningsih, F. A. (2017). Pengaruh Partisipasi Anggaran, Komitmen Organisasi, dan Sistem Pengukuran Kinerja Terhadap Kinerja Mnajerial ( Studi Pada Badan Keuangan Daerah Kabupaten Sukoharjo). Skripsi Fakultas Ekonomi Dan Bisnis Islam Institut Agama Islam Negeri Surakarta.

Purba, S. H. (2017). Pengaruh Sistem Pengukuran Kinerja , Sistem Penghargaan, Penerapan Total Quality Management dan Komitmen Organisasi Terhadap Kinerja Manajerial pada PT . Socfindo Medan. Skripsi Universitas Sumatra Utara.

http:/ / repositori.usu.ac.id/ bitstream/handle/123456789/863/130503154.p df? sequence $=1$ \&isAllowed $=y$

Rizandi, T., Nasir, A., \& Hariyani, E. (2015). Pengaruh Partisipasi Penyusunan Anggaran dan Kejelasan Sasaran Anggaran Terhadap Kinerja Manajerial SKPD dengan Desentralisasi dan Gaya Kepemimpinan Sebagai Variabel Moderating (Studi Pada Satuan Kerja Perangkat Daerah Kota Dumai). JOM Fekon, 2(1), 1-15. https://doi.org/10.1017/CBO9781107415324.004

Setyowati, L., \& Purwantoro. (2013). Analisis Pengaruh Partisipasi Penyusunan Anggaran Terhadap Kinerja Manajerial dan Kepuasan Kerja Pada Pemerintah Kota Semarang. Media Ekonomi \& Teknologi Informasi. Fakultas Ekonomi Dan Bisnis Universitas Dian Nuswantoro., 21(2), 66-79.

Simorangkir, E. N. (2013). Pengaruh Teknologi Informasi, Sistem Pengukuran Kinerja dan Sistem Reward terhadap Kinerja Manajerial dengan Total Quality Management Sebagai Variabel Moderating Pada Pt. Pelabuhan Indonesia I (Persero) Medan. Tesis Magister Sains Akuntansi Pada Sekolah Pascasarjana Universitas Sumatera Utara, Medan.

Syahputra, Z. (2014). Budget Participation on Managerial Performance: Related Factors in that influenced to Government's Employee (Study of Indonesian Local Government). Journal of Economics and Sustainable Development, 5(21), 95-100. http://iiste.org/Journals/index.php/JEDS/article/view/16172

Syafriadi. (2015). Pengaruh Partisipasi Anggaran, Gaya Kepemimpinan dan Komitmen Organisasi Terhadap Kinerja Manajerial (Studi Kasus Pada Universitas Pembangunan PancaBudi). Jurnal Ilmiah Integritas, 1(4), 71-85.

Sucitrawati, I. G. A., \& Sari, M. M. R. (2017). Pengaruh Partisipasi Penganggaran Terhadap Kinerja Manajerial Dengan Budaya Organisasi Dan Job Relevant Information Sebagai Pemoderasi. E-Jurnal Akuntansi Universitas Udayana, 20(3), 1791-1819.

Tims, M., Bakker, A. B., \& Derks, D. (2014). Daily Job Crafting and The SelfEfficacy - Performance Relationship. Journal of Managerial Psychology, 29(5), 490-507. https:/ / doi.org/10.1108/JMP-05-2012-0148

Vera, V. (2018). Pengaruh Akuntanbilitas Publik, Kejelasan Sasaran Anggaran dan Gaya Kepemimpinan Terhadap Kinerja Manajerial Pada Organisasi 
Perangkat Daerah (OPD) Kota Palembang. Thesis. Politeknik Negeri Sriwijaya.

Wahab, A., Mahmood, R., \& Bakar, S. Bin. (2015). How Do Managerial Competency and Self-Efficacy Affect Performance of University Leaders? Journal for Studies in Management and Planning, 1(6), 212-224.

Wasana, J. K. H., \& Wirajaya, I. G. A. (2015). Pengaruh Kompetensi, Motivasi, dan Komitmen Organisasi Pada Kinerja Manajerial Bank Perkreditan Rakyat Sekabupaten Gianya. E-Jurnal Akuntansi Universitas Udayana, 13(3), 828-856.

Wibowo. (2014). Manajemen Kinerja (Edisi Keempat). Jakarta: Rajawali Pers.

Wijaya, S. L., dan Lucyanda, J. (2016). Pengaruh Partisipasi Anggaran terhadap Kinerja Manajerial. Jurnal F. Ekonomi: JRAK, 1(1), 1-7.

Wiratno, A., Ningsih, W., \& Putri, N. K. (2016). Partisipasi Anggaran Terhadap Kinerja Manajerial Dengan Komitmen Organisasi, Motivasi Dan Struktur Desentralisasi Sebagai Variabel Pemoderasi. Jurnal Akuntansi, 20(1), 150-166. https://doi.org/10.24912/ja.v20i1.81

Yuniarti, S. (2019). Pengaruh Partisipasi Anggaran Terhadap Kinerja Manajerial Dengan Self Efficacy Sebagai Variabel Intervening. Jurnal Media Wahana Ekonomika, 15(4), 109-115.

Yudistira, C. G. P., \& Siwantara, I. (2013). Pengaruh Gaya Kepemimpinan Transformasional Dan Kompetensi Terhadap Kinerja Manajer Koperasi Di Kabupaten Buleleng. Jurnal Manajemen, Strategi Bisnis Dan Kewirausahaan. 